\title{
The India-Pakistani Military and Nuclear Arms Race in Post-Cold War Period: The Regional Security Complex in South Asia
}

\author{
Arfin Sudirman
}

Univesitas Padjajaran

\begin{abstract}
The article examines the India-Pakistani nuclear arms race and its effect to the regional security in South Asia today as a Cold War's legacy. By using regional security complex theory and qualitative method, this article argues that the balance of power and security dilemma principles also work in the region level due to the fact that both countries use nuclear weapons as a deterrence power, a similar pattern that also occurred during the Cold War era. External power such as US, China and Russia are actually aggravating the situation by selling the nuclear material (such as uranium) and technology to both countries regardless the future consequence. However, since multipolar system gives level of threat into more complex and broader sectors of security issues-not to mention the existence of non state actors such as terrorist groups, the regional security in South Asia is essential to prevent further damage to the nearby region. Therefore, the role of international community such as the UN to restore order in the regions is vital.
\end{abstract}

Keywords: Nuclear Arms Race, Balance of Power, India-Pakistan, Regional Security Complex

Artikel ini meneliti mengenai dinamika perlombaan senjata nuklir IndiaPakistan dan pengaruhnya terhadap keamanan regional di Asia Selatan sebagai warisan Perang Dingin. Dengan menggunakan teori regional security complex dan metode kualitatif, artikel ini menyimpulkan bahwa prinsip keseimbangan kekuasaan dan keamanan dilema juga bekerja di tingkat kawasan karena fakta bahwa kedua negara menggunakan senjata nuklir sebagai kekuatan penangkal, pola serupa yang juga terjadi selama era Perang Dingin. Kekuatan eksternal seperti AS, Cina dan Rusia sebenarnya memperparah situasi dengan menjual bahan nuklir (seperti uranium) dan teknologi ke kedua negara tanpa menghiraukan konsekuensi di masa depan. Namun, karena sistem multipolar memberikan tingkat ancaman ke sektor yang lebih kompleks dan lebih luas dari masalah keamanan - belum lagi keberadaan aktor non-negara seperti kelompok teroris, keamanan regional di Asia Selatan sangat penting untuk mencegah kerusakan lebih lanjut ke wilayah terdekat. Oleh karena itu, peran komunitas internasional seperti PBB untuk memulihkan ketertiban di daerah sangat penting.

Kata kunci: Perlombaan Senjata Nuklir, Balance of Power, India-Pakistan, Regional Security Complex 
Since its disintegration in 1947 and the following tensions were escalating over a disputed territory in Jammu and Kashmir, India and Pakistan conflict has never been resolved until today (Schofield 2006). In terms of military capability, both countries have developed their capacities to contest other states at the demise of Soviet Union in 1991. Recent studies found evidence that India and Pakistan are actually increasing the trend of developing Weapon of Mass Destruction (WMD) particularly nuclear weapons. One huge security issue occurred in 1998 when India decided to conduct nuclear tests and followed rapidly by Pakistan in the following years. It was considered as a contested nuclear and military power by two great nation states in South Asia region. Regardless the fact that some progress toward peaceful resolution between India and Pakistan have been agreed until today (such as Kashmir's line control between India, Pakistan and China), the shootout occurred in the Kashmir's Line Control in 2012 contributed to the complexity of the region. Thus, we can see that the legacy of the Cold War still competing in India and Pakistan relations and it could be considered as a flashpoint in South Asia's security aspect to stabilize the adverse region (Yahuda 2004, 215).

As a result, international community (particularly the US) fears that if the escalation of hostility is getting worse then the nuclear war would be imminent due to the distribution of nuclear powers in Asia (Ghosh 2003, 1-2). Therefore, this article attempts to discuss the relevant arguments of India and Pakistan Military rivalry as a legacy of post Cold War period and the essential role of international community to maintain status-quo in South Asia. Nevertheless, the question remains; as a legacy of Cold War era is the military rivalry between India and Pakistan could harm stability in the region? And how effective do the international actors such as United States (US) or United Nations (UN) to deter the forthcoming nuclear war in South Asia? In order to answer that question, we should look briefly to the historical perspective of how these two nation-states were disintegrated.

\section{Theoretical Framework}

Characterized by military competition of India and Pakistan, the regional security in the South Asia region seems to be relies heavily on both countries' balance of power. The situation is very common in all part of region around the world. We can see the similar pattern also occurs recently in South East Asia where China's military power in the disputed South China sea are balanced against the some ASEAN member states such as Vietnam and Philippines by engaging military cooperation with the US. 
In East Asia region we can also see how China and North Korean military force are balanced by the presence of US armed forces in Japan and South Korea. Therefore, to understand the balance of power that is happening in South Asia as the legacy of the Cold War period, we should see the theory of structure in international system as one of the mainstream approach in International Relations.

According to Waltz (In Jackson and Sorensen 1999, 51-53), neo-realism focused on 'structure' of international system and its consequences. Firstly, the anarchic structure on international system leaves no world-govern means order of the world is unattainable. Secondly, the international system is divided of interacting units between states and defers it on their relative power which Waltz identified it as 'relative capabilities'. Therefore, according to Waltz, to preserve autonomy and sovereignty is a nature of a state and that is the reason for anarchy to survive. Originally, the notion of Neorealism emerged in the Cold War as critics from its predecessor, the classical realist and the Neoliberalism. In addition, Smith (1996, 1114) considered it as a pragmatic approach in the epistemological debate in which 'scholars search for the same kinds of laws and regularities in the international world as they assume characterize the natural world'. During the Cold War era, the bipolarity system, the state-centrism notion and the confrontation were the central issues in understanding the international relations. The classical realist concept of Balance of Power where powerless countries will determine to pursue an international position from the "underdogs" to the "privileged" place was still existed virtually (Carr in Jackson and Sorensen 1999, 41-42).

The Neo-Realism theory in this sense has become a new perception in explaining international behavior of states. Kenneth Waltz is NeoRealism's prominent who focused on 'structure' of international system and its consequences. He argued that the anarchic structure on international system leaves no world-govern means order of the world is unattainable. Subsequently, the international system is divided of interacting units between states and defers it on their relative power which Waltz identified it as 'relative capabilities'. Therefore, according to Waltz, to preserve autonomy and sovereignty is a nature of a state and that is the reason for anarchy to survive. The Balance of Power (BoP) system exists not because of survival as argued by classical realist outlook but furthermore due to the nature of a state in anarchical structure of international system. Moreover, neorealist recognizes the existence of cooperation between states. However, that cooperation is aimed to maximize power capabilities, 
defend autonomy and increasing its bargaining chips (Waltz in Jackson and Sorensen 1999, 51-53).

The security complexity in term of Neo-realism, "revamped the old paradigm to accommodate non-military components of power into its competitive logic of accounting for state relations" (Crouch 2004, 142). For example, since the September 11, 2001, the US has been revising their political, military and economic policy toward the Asian Countries by improving their relationship with Japan, India and Taiwan to isolate China as their potential competitor (Gilboy and Heginbotham 2002, 99-100). Presumably, it is obvious that America's strategic interest in Asia is based on Neo-realism idea of anarchic structure of international system by using the nature of BoP system in Asian countries (i.e. India's military development against Pakistan or Taiwan insecurity against China by providing military and economic aid). Improvements of military and economic cooperation towards those Asian countries are aimed to maximize power capabilities (i.e. isolating China) or increasing their bargaining chips (i.e. collecting support for 'War against Terrorism'). Therefore, we can see that Neo-realism also is one of the most capable theoretical frameworks in understanding how balance of power has been maintaining status quo in South Asia's regional security since the end of Cold War era.

\section{A Brief History of India-Pakistan Conflict}

In order to understand the roots of India-Pakistan conflict, we should see the historical background of both countries' relations. According to More (2004, 1-13), Indian people regardless their ethnics and religions (Hindus, Sikhs and Muslims) were united to fought against British colonies long before they implementing the partition. The tension between Muslims and Hindus to segregate themselves was actually started since 1867 when Sir Sayed Ahmed Khan insisted a separate Muslim State. By the following years, the British complied the demand by creating separate electorates for different classes and eventually turned as the birth of "Pakistan concept" designed by Choundhary Rahmat Ali in 1933. The Pakistan concept itself compromised almost all North-Western provinces. The partition of India itself occurred in 1947 and considered as a historical alteration to the Indian subcontinent history. However, in the following periods, civil war were erupted consequently human costs was massive and so was economic damage due to a bilateral class's society between two major religions; Hindu and Muslims. Subsequently, in order to prevent any further casualties caused by civil war, Mohammed Ali Jinnah, Indian politician 
and longtime leader of the Muslim League later known as a founding father of Pakistan and its first governor-general (Encarta, 2005), proposed the "Two-Nations" theory on a religion basis (Hindus and Muslims) which was eventually made India and Pakistan fragmented. The disputed area in Kashmir also contributed to the tension between both nation-states. The first intervention by Pakistani army was occurred in May 1948 which provoked The First India-Pakistan War and later brought United Nations to resolve the Kashmir crisis. Nevertheless, the Kashmir crisis has never yet been settled until today due to the hostility between both countries and the insurgency taking place by various separatist groups demanding Kashmir's self determination (Ghosh 2003, 1-5).

The second India-Pakistan War occurred in 1965 also in an attempt to take over Kashmir by both countries. Ironically, an open war was actually occurred during a ceasefire arranged by the United Nations Security Council. Apparently it was initiated by Pakistanis infiltrations into Indian-Kashmir to organize insurgency against Indian authority. As a consequence, the full-scale war came up to its climax on September 1965 when India retaliate the attack to city of Pakistan, Lahore. In the end, the new ceasefire was concluded on the Tashkent Declaration in January 1966 and temporarily ended the war. In 1971, the Third India-Pakistan War occurred again and this time resulting the independence of Bangladesh. By the following years, the militants committed an insurgency in Kashmir to demand a separatist state from India, Pakistan and even China which makes a perpetual security complexity in South Asia until today (Sathasivam 2005, 8-15). Therefore, in my opinion, the hostility and the military rivalry between India and Pakistan in a broad sense can be considered as a never ending story which has already taken millions of casualties and aggravated by the lack of international community's consideration to the crisis.

On the contrary, one of the significant external actors to ever influence these two nations-states to settle the hostilities was the United Nations Security Council whom pioneered the ceasefire agreement during the first Kashmir War on January 1, 1949 (Sathasivam 2005, 8). However, the first attempt by the UN met with unsuccessful result when the second Kashmir war broke out on August 15, 1965 between both countries with the same objective-to take over disputed area, Kashmir. Although it was occurred within a month, the lost and casualties were larger than the first war. Both sides suffered 6800 human casualties and did not achieve the main objective from the war-especially Pakistan. Eventually, on September 22, 1965, the United Nations Security Council passed an unconditional 
ceasefire from both countries marked the end of second India-Pakistan war (Kalyanaraman 2015). Subsequently, the ceasefire plan mandated by the UN did not go efficiently as the Third India-Pakistan war broke out. This time, resulted the independence of Bangladesh in 1971 and also without the UN intervention (Sathasivam 2005, 9-10). Therefore, we can see that the UN did not put too much effort in order to ease the tensions between India and Pakistan. Proved by many wars broke out after the UN initiated the peaceful resolution to put the hostility down. As consequences, economic losses and human cost were inevitable as casualties of the infamous wars. In fact, after the 1971 third India-Pakistani war, both countries marked the beginning of nuclear technology rivalry-or arms acquisitions-by increasing their military spending to test the nuclear capabilities (Kegley and Wittkopf, 2004: 209-210). First of all was India in 1974 carried out a 12-15 kiloton nuclear detonation at its Pokhran test site in the Rajasthan desert and characterize the test as a "peaceful nuclear explosion" but apparently was rejected by the international community (Sathasivam 2005, 56). On the other hand, in 1977 Pakistan established the hub of nuclear weapons program in the Kahuta facility-acquired by Germany-where highly enriched uranium (HEU) is formed into weapon cores (Rajain 2005, 285-6). Thus, the nuclear technology rivalry between India and Pakistan marked the uncertainty of security and stability in South Asia and the peaceful resolution is obviously depend on the global community's willingness to deter such global nuclear war before its too late. International Relations' scholars also have to contribute an effort to cease the hostility in these two adjacent countries because the military rivalry itself has become an international concern of a nuclear war in South Asia.

During the cold war, India's national security was worsened by three major wars between Pakistan and the Balance of Power was created in an alignment commitment to two major powers (US and Soviet Union). At that time, China also contributes the difficulties of India's security position because of the war in 1962 (Yahuda 2004, 34). However, Soviet Union and United States' rivalry gave India a major role during the cold war. According to Wriggins (1992, 102-5), Soviet Union supported Indian position in the Kahsmir debates at the United Nations and pledged to help Indian economic development. In 1961, the Soviet Union started a modest military transfer program, and eventually established a possibility of cooperation within India of MIG-21s. Therefore, the Soviet-Union cooperation with India gave an impression to the Chinese government that India had been backed up by Moscow in terms of military and economic aspects so China could not intervene with the India-Soviet Union alignment. On the other hand, 
this was also considered as a signal to Pakistanis-backed US assistance to reconsider any attempt to strike India. During the Cold War period, US politically and military intervention in South Asia (particularly in Pakistan) was purposed to overthrown an established set of authorities that had dissimilar ideology-communist-with the US as a part of 'Containment' policy articulated by George Kennan in 1946 (McGrew 2002, 167-8). Therefore, after the establishment of the Baghdad Pact [later the Central Treaty Organization (CENTO)] along with Iran and Turkey in 1959, US sought Pakistan as its strategic ally in South Asia because Pakistan's proximity to the Gulf and south of Soviet Union made it easier job for the US to implement the containment policy to secure South Asia and the Gulf from communist threat as a consequence of Cold War's domino effect (Yahuda 2004, 45). Consequently, Pakistan managed to 'balance' the IndiaSoviet Union alignment by having a security relationship with the US and also cooperation in CENTO commitment with Iran and Turkey (Wriggins 1992, 103). In principle, the alliances have a function to enhance their members' power capabilities and increase bargaining position with other states in a response to a perceived threat (Goldstein 2003, 102). According to classical realist's view, this movement is considered as a reflection of Balance of Power system where small countries will determine to pursue an international position from the "underdogs" to the "privileged" place (Carr in Jackson and Sorensen 1999, 41-42). The India-Soviet Union alignment and the CENTO commitment also reflect of how Security Dilemma worksin Hobbesian way-in perceiving other states both as an ally or as a security threats when it comes to think in their self-interest (Wendt 1999, 269). Thus, we can see that during the cold war, India and Pakistan also become major actors in the US and Soviet Union's rivalry instrument in South Asia which made the regional security become more ambiguous even after the end of Cold War in 1991 due to the Balance of Power principle works as it should be.

\section{Security Complex in The South Asia Region}

Traditionally, the study of International Relations focused on the questions of war and peace during the Cold War period. However, after Soviet Union collapsed in 1991, the Security Studies that was dominated the study of International Relations before 1991 has been degraded by the movements of diplomats, the alliances and the seek trough peaceful resolution. Eventually, every state in the world is starting to search for multinational cooperation and focus on the economic development (Goldstein 2003, 4-5). Apparently, the condition is factually dissimilar to what happen in 
India and Pakistan. The fundamental problems of dividing the two nations remained unresolved until this day. The nuclear war may be occurred in South Asia at any given times if global community does not act to put off the hostility (Gardiner 2003, 55-57).

Essentially, the rivalry took place long before the aftermath of the Cold War. It was begun after the third India-Pakistani war in 1971 when India tested nuclear explosion in "peaceful purposes" in Rajasthan desert (which was condemned by international community) (Sathasivam, 2005, 56) and followed in 1977 by Pakistan who established the hub to develop highly enriched uranium (HEU) of nuclear weapons program in the Kahuta facility-acquired by Germany-alleged to formed into weapon cores (Rajain 2005, 285-6). Approximately 30 years later-after the cold war ended-, both countries shocked the international community in 1998 when India carried out a series of nuclear tests and as a result of the Balance of Power principle, Pakistan followed with their series of nuclear tests on the same year. Consequently, the US and other countries that concerned about this "symptom toward nuclear war" imposed several sanctions of both India and Pakistan (Sathasivam 2005, 56). Furthermore, according to the report published by Australia's Senate Foreign Affairs, Defense and Trade References Committee in June 1999 (Report of the Senate Foreign Affairs, Defense and Trade References Committee 1999, 15-17), since the conflict between India-Kashmir-Pakistan (partly China) has never been resolved, the 1998 nuclear test program had confirmed that India and Pakistan are willing to continue their nuclear research and development program into nuclear weaponry in order to protect their sovereignty. Thus, the Post Cold War period contributes to the competition of Weapon of Mass Destructions (WMD) development between India and Pakistan which potentially could threat status-quo in the South Asia region.

For India, the end of cold war brought them to reassess their security policy because the demise of India-Soviet strategic alignment. As consequences, India declined to sign the Nuclear Non-Proliferation Treaty (NPT) because the security uncertainty since Soviet has gone and the threat posed by its neighbors (Pakistan and probably China). Similarly, Pakistan is confirmed nuclear powers country and widely believed to possess nuclear weapons, declined to sign the treaty with the same reason as India (Rublee 2017). Therefore, we can see that both countries' military rivalry by refusing to sign the NPT treaty is allegedly part of the cold war inheritance and contribute to the complexity factor of global nuclear disarmament. 
In regards to both countries' security strategic thought in enhancing their military capabilities, taking over Kashmir and protect their sovereignty, India and Pakistan have their own security policy to achieve those goals. According to Sathasivam (2005, 145-7), for India, the strategic security policy focus on the geographical element of the subcontinent encompassing entirely to its northwestern and northeastern borderlands and the northern waters of the Indian Ocean (this is known as the inner ring') as their first priority security concern. The 'outer ring' which consists of the Arabian Peninsula, Iran, Afghanistan, Tibet, Southeast Asia and the southern reaches of the Indian Ocean as their secondary priority security policy. Lastly, the third ring which consists particularly of the great powers of the world. In order to maintain India as major power in the South Asia region, India also isolates the subcontinent from all external powers and influences which would potentially harm Indian primacy and restrict any form of freedom of action in the region-this is known as 'Indira Doctrine' of Indian security policy guidelines.

In terms of strategic defense policy, India has spent their vast resources and GDP mainly to the military expenditures. According to the recent studies by Asian Survey (Hilali 2001,749-5), India is considered as one of the largest standing armies in the world, supported by large Indian population. Currently, Indian military expenditures are about two and a half times compared to all South Asian neighbors combined. The Indian government has spent over $3.3 \%$ of its GDP solely to boost its armed forces. In 1996-1997, the government spent Rs. 36 billion to raise its armed forces and expand the defense budget to Rs. 356 billion ( $\$ 9.5$ billion). The 1996-1997 Defense Services estimates allocated Rs. 111.28 billion ( $\$ 3.6$ billion) for the army, Rs. 36.18 billion ( $\$ 1.16$ billion) for the air force, and Rs. 13.52 billion ( $\$ 0.435$ billion) for the navy and overall expenditure for three services combined was Rs. 68.32 billion ( $\$ 2.1$ billion) (SIPRI in Hilali 2001, 750). Furthermore, the coalition government headed by the Bharatiya Janata Party (BJP) has increased its defense budget by $28.2 \%$ (military expenditures increase up to $\$ 13.5$ billion and the highest hike in Indian history) (Hilali 2001, 750). In details, government allocation for ground forces was increased by $\$ 543$ million to $\$ 6.7$ billion, for the air force by $\$ 403$ million to $\$ 1.83$ billion and for the navy by $\$ 163$ million to $\$ 939$ million. During the last decade, India imported $\$ 12.2$ billion amount of total defense equipment in order to modernize weapon programs. As the program of weapon modernization continue after the nuclear test in 1998, Indian government increased defense research and Development expenditure from Rs. 10.8 billion in the same year to Rs. 23.2 billion in the 
February 2000 budget (Hilali 2001, 752). This defense spending also part of funding for military research by $12.5 \%$ and for atomic research by $33 \%$ and by 2005 , the Indian military expenditures would be increased to $70 \%$. Therefore, we can see that in order to protect India's territorial sovereignty from emanate threats by its neighbors such as Pakistan or China, India's security policy is determined to boost their annual military spending and apparently has become uncontrolled without considering other internal problems such as corruption and poverty.

On the other side, Pakistan also spends a large amount of their resources and GDP mainly for the security concern. According to Sathasivam (2005, 149-2), Pakistan's strategic security policies almost similar with Indian understanding of strategic thought and tend to follow Indian's security policy. As argued before, in 1974, India detonated its firs nuclear device in Rajasthan as a 'peaceful nuclear explosion', and 3 years later Pakistan established the hub to develop highly enriched uranium (HEU) of nuclear weapons program in the Kahuta facility and alleged to formed into weapon cores. Subsequently, in 1998, both countries tested its nuclear weapon and we can see the pattern that it was always initiated firstly by India and then Pakistan followed it. Therefore, Pakistan's security policy to boost its weapon and nuclear technology always provoked by Indian's defense capability (due to Balance of Power principle) and consequently, the nuclear arms race continues to the uncertainty of apparent nuclear war.

Second strategy that most important to Pakistan's security is by considering the enormous quantitative and qualitative advantage in terms of population owned by Indian armed forces compared to Pakistan's armed forces (Sathasivam 2005, 155-156). Essentially, India has more significant advantage over Pakistan in terms of its population size and GDP and thus it could benefits also to the Indian armed forces. India in 2002/2003 had a population of about 1,040,245,000 and a GDP of approximately US $\$ 505$ billion and spent mostly for its armed forces as has been described previously. On the other hand, Pakistan had a population of about $147,549,000$ and GDP of about US $\$ 68$. Approximately, US $\$ 2.8$ billion of its GDP spent for armed forces comprising 620,000 active-duty and 513,000 reserve military personnel. Its main military equipments encompassing about 2,450 main battle tanks, about 1,700 artillery pieces and rocket launchers. In terms of Pakistan nuclear weapons program, apart from European countries, China has become a major supplier of nuclear technology and Chinese assistance in uranium enrichments could be a significant factor to Pakistan's WMD development during the Zia 
regime. As a result, with Chinese assistance of developing nuclear weapons program, in 1989 Pakistan tested its short-range nuclear missile Hatf-I and Hatf-II ballistic missiles and each of them has a range of 80 kilometers and 180 kilometers which could strike any place in India and other places in South Asia region. The US also contributed to Pakistan's military and weapon development by approving to sell $\$ 368$ million worth of military hardware to Pakistan under the Brown amendment in 1996 Foreign Assistance Act (Ahmed 1999, 186-192).

Since the end of the cold war, Pakistan has spent a total of US\$2705 million on military expenditure and the navy was the major priority having the largest allocation of US $\$ 1800$ million for purchasing. This is because historically, Pakistani navy has developed powerful naval strategy to counter the Indian threat and has specific offensive sea denial strategy emphasizes on submarines and maritime aircrafts as their ultimate forces. The Pakistan military strategy relies on the primacy of its navy power in the 1990 s by purchasing the armada from UK and France (Sakhuja 2002, 493-500). This is the illustration of Pakistan's naval military expenditure:

Figure 1: Pakistan's naval military expenditure

\begin{tabular}{|l|l|l|l|l|l|}
\hline FY & Source & Platform & QTY & Old/New & Cost(US\$Mn) \\
\hline $1992-93$ & UK & Frigate & 6 & Old & 150 \\
\hline $1994-95$ & France & $\begin{array}{l}\text { MineHunt- } \\
\text { ers }\end{array}$ & 3 & New & 350 \\
\hline 1994-95 & France & Submarines & 3 & New & 1300 \\
\hline
\end{tabular}

Source: Sakhuja, V., (2002). Pakistan's Naval Strategy: Past and Future. Strategic Analysis, Institute for Defense studies and Analyses New Delhi, 26 (4), p. 500.

As a Balance of Power comparison between India and Pakistan's defense capability, the table below illustrates the military and nuclear technology on both countries (Cloughley 2005, 50):

Figure 2: India and Pakistan's defense capability

\begin{tabular}{|l|l|l|}
\hline Country & India & Pakistan \\
\hline $\begin{array}{l}\text { Armed forces } \\
\text { strength }\end{array}$ & $1,306,500$ & 620,000 \\
\hline Armored vehicles & 6,860 & 3,727 \\
\hline
\end{tabular}




\begin{tabular}{|l|l|l|}
\hline Combat aircraft & 911 & 417 \\
\hline Major naval vessels & 60 & 18 \\
\hline
\end{tabular}

Source: Jane’s Sentinel Security Assessments (sentinel.janes.com).

Figure 3: India's nuclear-capable ballistic missiles

\begin{tabular}{|l|l|l|l|}
\hline Missile & In-service date & Range (km) & Numbers \\
\hline Prithvi 150 & 1994 & 150 & 60 \\
\hline Prithvi 250 & 1999 & 250 & 70 \\
\hline Agni 1 & 2002 & 700 & 10 \\
\hline Agni 2 & 2000 & 2,000 & 20 \\
\hline Dhanush & Demonstrator & 250 & nil \\
\hline
\end{tabular}

Source: Jane's Strategic Weapons Systems (jsws.janes.com).

Figure 4: Pakistani nuclear-capable ballistic missiles

\begin{tabular}{|l|l|l|l|}
\hline Missile & $\begin{array}{l}\text { In-service } \\
\text { date }\end{array}$ & Range (km) & Numbers \\
\hline Ghauri & 1998 & 1,300 to 1,800 & 20 \\
\hline Shaheen 1 & 1999 & 750 & 25 \\
\hline Ghaznavi & 2003 & 290 & 5 \\
\hline Shaheen 2 & 2006 & 2,000 & nil \\
\hline
\end{tabular}

Source: Jane’s Strategic Weapons Systems (jsws.janes.com).

According to the data above, we can see that the strategic arms race between India and Pakistan is based on the Balance of Power principle and the anarchic international system. It is illustrated in how both countries concern about their survival (sovereignty) and considered Kashmir as a security flashpoint to maintain status-quo in the region. Furthermore, the multipolar system is a heritance of post cold war era and resulting in intangible threats and imprecise level of uncertainty as seen recently by the growing of militants claiming Kashmir's independence such as Hizbul Mujahideen and The Jammu and Kashmir Liberation Front (JKLF) (Kegley and Raymond 1994, 48-49).

The Indo-Pakistan arms races can be elaborated in theoretical framework of analysis; the military rivalry between India and Pakistan also can be explained with the concept of Security Dilemma posed by states to 
survived and Neo-realism that focus on 'structure' of international system and its consequences (Jackson and Sorensen 1999, 51). According to John Herz (In Waltz 1979, 186), security dilemma means that states' motivation in increasing its military budget and boosting its defense capacity in an attempt for the sake of security because states tend to unsure of one another's intentions who in turn responds by arms forces. Furthermore, as argued by Barry Buzan (1991, 311-2), who also contributed in Security Studies stated that the security dilemma can be measured by regional Arms races in military terms. In addition, Buzan (In McGrew and Brook 2002, 71) also argued that countries in a region have established guarantee arrangements to reduce potential threats as a result of security dilemma posed by their neighbors.

Likewise, in terms of nuclear technology in both countries, Holsti (1995, 107-8) argued that the motivation of a state to develop nuclear weapons is to achieve the status of a "nuclear power" by purchasing it from other countries like US, Russia or China-and thus create a nuclear interdependence. Kenneth Waltz proposed a neo-realism approach that can apply to IndiaPakistan arms race firstly because the anarchic structure on international system leaves no world-govern means order of the world is unattainable. Secondly, the international system is divided of interacting units between states and defers it on their relative power which Waltz identified it as 'relative capabilities'. Therefore, according to Waltz, to preserve autonomy and sovereignty is a nature of a state to survive in anarchic international system and also that explain of how India and Pakistan are determining to acquire tons of arms equipment and nuclear technology for their security concern. Furthermore, Neorealist recognizes the existence of cooperation between states as seen when India associated with Soviet during the cold war and Pakistan affiliated with US and China. However, that cooperation is aimed to maximize power capabilities, defend autonomy and increasing its bargaining politics (Waltz in Jackson and Sorensen 1999, 52-53). Hence, for many developing countries such as India and Pakistan, visible symbols of economic industrialization and modern technology in military terms are important sources of status and prestige in global community and therefore, it is considered as rivalry without long-term purposes.

\section{The Involvement of Great Powers in The Region}

In regards of India and Pakistan's military cooperation with external actors, superpower countries such as United States and Russia did not realize that the security policy imposed to India and Pakistan might not be 
utilized for sake of their national security interest, in fact it would aggravate the security status-quo in the region. Nonetheless, the US and Russia did it in order to maintain a sufficient, boosting national economic capacity and taking profit by exporting the arms technology who are interested in nuclear technology as a "status"-India and Pakistan. As Buzan (1991, 3534) stated that the rivalries and conflict occurred between India and Pakistan may be stimulated by the spreading of nuclear materials, knowledge and technology-weapon investments by other states just for their economic interests. In my opinion, these are reasons why India and Pakistan enhancing their arsenals-and nuclear technology-in order to protect their sovereignty from external threat that emanates from their neighbors' security dilemma and also to boost international interests over their nuclear technology by purchasing nuclear materials and technology from other super power states. Thus, since the peaceful resolution for India and Pakistan has not been resolved yet, the role of security dilemma posed by both countries and the nuclear technology contribution by external factors will dominate the situation in South Asia and potentially, the nuclear war will be inevitable. Therefore, the role of International community to deter the nuclear war is essential.

In order to preserve the security status-quo in South Asia, the role of International community particularly the major powers is crucial to deter the nuclear war due to the Balance-of-Power arms race escalation. According to Saighal $(2004,87)$, the positive solutions would be preserving south Asia stability by co-optation of the smaller South Asian economies into the larger Indian economy, border demilitarization on both sides especially on the Tibet and settlement of the China-India territorial dispute, Confederation of Central Asian Republics-on the lines of the EUguaranteed by Russia, China, India, EU and the US, de-jihadisation of Pakistan and finally, prevention of the spread of militant/orthodox Islam in South Asia. In my opinion, one of the most essential powers to deter the nuclear war in South Asia would probably the United Nations. However, as has been discussed previously, the UN did not put too much effort to ease the tension proved by that many UN-mandate ceasefires was not prolong effectively (Sathasivam 2005, 9-10). Furthermore, since US and Russia's effort does not seem too beneficial to the nuclear war deterrence, more likely the UN is the most credible actor to do so by imposing the sanctions to both countries through UN Security Council mandate or renew the status of Kashmir as a potential flashpoint in Indo-Pakistani relations (Ganguly 2001, 311). It might not be the best resolution but at least it could prevent the uncertainty of nuclear war. 


\section{Conclusion}

To conclude, the tension between India and Pakistan actually had occurred since the end of British rule and the partition of India in 1947 and still continues until the end of Cold War era. The conflict was broke up in the following years between India and Pakistan in order to take over the disputed territory Jammu and Kashmir. The complexity of the conflict was worsening by the situation of cold war period when India aligned itself to the Soviet and Pakistan to the US. However, after Soviet collapsed, India has to reevaluate its security policy to be self-reliant without Soviet's aid. Consequently, India saw that it is important to boost its military power to defend itself from external threats (such as Pakistan or China). One turning point was India decided to withdraw from the Nuclear Non-Proliferation Treaty (NPT) followed by Pakistan which considerably nuclear states. The situation deteriorated in the year of 1998 when India successfully tested its Nuclear weapon and also followed by Pakistan which marked the new era of nuclear arms race. The Balance of Power and Security Dilemma principles work in the nuclear arms race between India and Pakistan. As a consequence, the escalation of military and nuclear power acquired by both countries is gradually increasing until today. External power such as US, China and Russia are actually aggravating the situation by selling the nuclear material (such as uranium) and technology to both countries regardless the future consequences. However, since multipolar system gives level of threat into more complex and broader sectors of security issues, the status-quo preservation in South Asia region is essential to prevent intangible threats grow higher. Therefore, the role of UN to impose such sanctions to halt the hostility in the regions is vital. By this it is save to say that maintaining the security in the region based on international commitment is strategically essential.

\section{Reference}

\section{Book and chapter in book}

Buzan, B., 1991. People, states and fear: An agenda for international security studies in the post-cold war era. Boulder, Colorado: Lynne Rienner Publisher.

Buzan, B. 2002.The Asia-Pacific: what sort of region in what sort of world?. In Brook, C. and McGrew, A. eds., Asia-Pacific in the new world order. London and New York : The Open University. 
Ganguly, S., 2001. "The Flash-Point of South Asia: Kashmir in IndoPakistani Relations". In The Post-Colonial States of South Asia (pp. 311-325). Palgrave Macmillan, New York.

Gardiner, S. 2003. "It Doesn't Start in Kashmir, and It Never Ends Well". In Goldstein, J. S. 2003. International Relations (pp. 55-57). 5th ed. New York: Longman.

Ghosh, A., 2003. Indo-Pak Conflict: Threat to South Asian Security. Reference Press.

Goldstein, J. S. 2003. International Relations. 5th ed. New York: Longman

Holsti, K.J., 1995. International politics: a framework for analysis (No. 327). New Jersey: Prentice-Hall,.

Jackson, R. and Sørensen, G., 1999. Introduction to international relations: theories and approaches. New York: Oxford university press.

Kegley, C.W. and Raymond, G.A., 1994. A multipolar peace?: great-power politics in the twenty-first century. New York: St. Martin's.

Kegley Jr, C.W. and Wittkopf, E.R., 2004. World Politics Trends and Transformation (Belmont. USA: Thomson Wadsworth.

More, D.R., 2004. India and Pakistan: Fell Apart. Jaipur: : Shruti Publications.

McGrew, A,. 2002. Restructuring foreign and defence policy : the USA. In A. McGrew, \& C, Brook (Eds.), Asia Pacific in the New World Order (pp. 167-168). London and New York: The Open University.

Rajain, A., 2005. Nuclear Deterrence in Southern Asia: China, India and Pakistan. SAGE Publications India.

Saighal, V, M,G. 2004. Global Security Paradoxes 2000-2020. New Delhi: Manas Publications.

Sathasivam, K., 2005. Uneasy neighbors: India, Pakistan and US foreign policy. Burlington: Ashgate Publishing Company.

Waltz, K., 1979. Theory of international politics. New York: McGraw-Hill, Inc.

Wendt, A., 1999. Social theory of international politics. Cambridge University Press.

Wriggins, W. H. 1992. South Asian Regional Politics. In Wriggins, W.H. (Eds), Dynamics of Regional Politics (pp. 102-105). New York: Columbia University Press.

Yahuda, M. 2004. The International Politics of the Asia-Pacific. London 
and New York: RoutledgeCurzon, Taylor \& Francis Group

\section{Journal and Online Journal}

Ahmed, S., 1999. "Pakistan's nuclear weapons program: Turning points and nuclear choices." International Security, 23(4), pp.178-204.

Cloughley, B., 2005. Detente for India and Pakistan?. Jane's Intelligence Review, 17(7), pp.48-50.

Hilali, A.Z., 2001. India's Strategic Thinking and Its National Security Policy. Asian Survey, 41(5), pp.737-764.

Kalyanaraman, S. 2015. The Context of Cease-Fire Decision in the 1965 India-Pakistan War. Institute for Defense Studies and Analysis Special Feature.

Rublee, M, R. 2017. India-Pakistan Nuclear Diplomacy: Constructivism and The Prospects for Nuclear Arms Control and Disarmament in South Asia. Contemporary Security Policy, 38 (1), pp. 1-8.

Sakhuja, V., 2002. Pakistan's Naval strategy: Past and future. Strategic Analysis, 26(4), pp.493-507.

\section{Official Report}

Report of the Senate Foreign Affairs, Defense and Trade References Committee. (1999). The 1998 Indian and Pakistani Nuclear Tests. Canberra: The Parliament of the Commonwealth of Australia.

Stockholm International Peace Research Institute (SIPRI). Ed. SIPRI Yearbook 1996-97, Armament and Disarmament. Oxford: Oxford University Press. 1998. p. 425.

\section{Online article}

Encarta.2005. Jinnah, Mohammed Ali. Available at: Microsoft @ Encarta ® Reference Library 2005. C 1993-2004 Microsoft Corporation. All rights reserved.

Schofield, V. 2006. Kashmir: The Origins of the dispute. Available at: $\quad$ http://news.bbc.co.uk/1/hi/world/south_asia/1762146.stm [Retrieved March 13, 2006] 